ISSN 2078-5526. Вісник Львівського університету. Серія педагогічна. 2021.Випуск. 35.С. 73-85 Visnyk of Lviv University. Series Pedagogics. 2021. Issue. 35. P. 73-85

УДК 378.147:811.581.11

DOI: http://dx.doi.org/10.30970/vpe.2021.35.11309

\title{
CFL STUDENTS' PERCEPTION OF DISTANCE EDUCATION (BLENDED MODEL) DURING THE COVID-19 PANDEMIC IN UKRAINE
}

\author{
Olha Dalte \\ Kyiv National Linguistic University, \\ Velyka Vasilkivska Str., 73, Kyiv, Ukraine, UA-03150 \\ olha-dalte@knlu.edu.ua
}

Due to COVID-19 pandemic, Ukraine, as well as many other countries worldwide, has transferred the educational process online in order to minimize the spread of infection. This paper aims to analyze the perception of bachelor students majored in Chinese Philology towards such an urgent change in their educational process. As students are one of the key stakeholders of any learning process, it is extremely important to understand what they think about the effectiveness of distance education in the form of blended model. In particular, it is crucial to realize in which way such an urgent transfer has influenced the development of pronunciation, vocabulary, grammar, typing, receptive (listening and reading) and productive (speaking and writing) skills.

In order to fill the aforenoted gap, current research analyzed the data collected through an anonymous online questionnaire via Google Forms. The key participants are 40 BA students majored in Chinese Philology who study in two different institutions Kyiv National Linguistic University (Kyiv, Ukraine) and International Humanitarian University (Odessa, Ukraine). As two institutions use different teaching methods, curriculum and tools, the students' answers will be unbiased, which in turns contributes to the reliability of the results. The findings indicate that the traditional classroom has to transform and students are not afraid to meet the new blended educational model. The paper points to the fact that students as key stakeholders support the move towards global trends in modern educational technologies The majority of respondents believe that such a switch is at least the same effective for learning an eastern language as a traditional classroom. Students hope that in future, when COVID-19 pandemic will be finally defeated, they will still have opportunities for blended education, as it is convenient, productive and engaging trend. Moreover, the paper argues how students' perception correlates with the previous researches and points to the gaps for future investigations.

Keywords: distance education, blended learning model, traditional classroom, students' perception, Chinese as a foreign language.

Introduction. Nowadays, the whole globe has faced an ultimate challenge brought by the COVID-19 crisis and its associated effects on the regular functioning of merely all aspects of everyday life. The educational system is not an exception. As burning issues require fast but thoughtful solutions, in order to stop the spread of infection, many countries decided to adopt modern technologies and

(C) Dalte O., 2021 
ISSN 2078-5526. Вісник Львівського університету. Серія педагогічна. 2021. Випуск 35

switch to online distance learning (Cahapay, 2020; Morze, \& Smyrnova-Trybulska, 2021; Stukalo, \& Simakhova, 2020; Wang, \& East, 2020). However, Ukrainian educational system lacks data on how such a move influences achievements of university students who learn foreign languages. One should note that in order to master a foreign language, any learner should develop a wide range of specific skills and competencies, including listening, reading, speaking, writing, pronunciation and grammar (Al Zumor et al., 2013). When it comes to characterbased language, like Chinese, for instance, the situation gets even more complicated, as each learner should master the hieroglyphics and typing skills as well.

As the influence of distance education is not fully investigated, this paper focuses on the students' perception of such initiative in Ukraine and aims to analyze the effectiveness of blended model towards the development of different language skills in comparison to the traditional classroom. It is worth noting that many publications investigate the same question from the teacher's perspective (Bahari, \& Salimi, 2021), while neglecting the learners' point of view, even though the last ones are the key stakeholders and main participants of any educational program. In order to meet the set goal, current research conducts literature review on the state of distance education development in Ukraine and analyses data retrieved from 40 university students who learn Chinese as a foreign language in Kyiv and Odessa.

Literature Review. Even though there is no one definition of blended learning, as it has different models, many researchers agree that its main feature lies in combining elements of online learning and guided face-to-face interactions (Kanuka, \& Rourke, 2014, p. 22). As modern technologies become a common part of our everyday life, one can assume that this trend cannot help but become the new stage of the educational process, or a so-called "inevitable evolution of the educational system". Many researchers have already proved the effectiveness of blended models for university students. For instance, Zhang and Zhu (2018) analyzed the academic performance of more than 5000 university students in Beijing who learned English as a second language (ESL) and came to a conclusion that blended learning is much more effective than a traditional face-to-face classroom approach.

Boom of Distance Education (Blended Model) in Ukraine. One can easily trace the interest of Ukrainian scholars towards the application of new technologies for teaching foreign languages in higher education by checking the number of Google scholar publications in different years. 


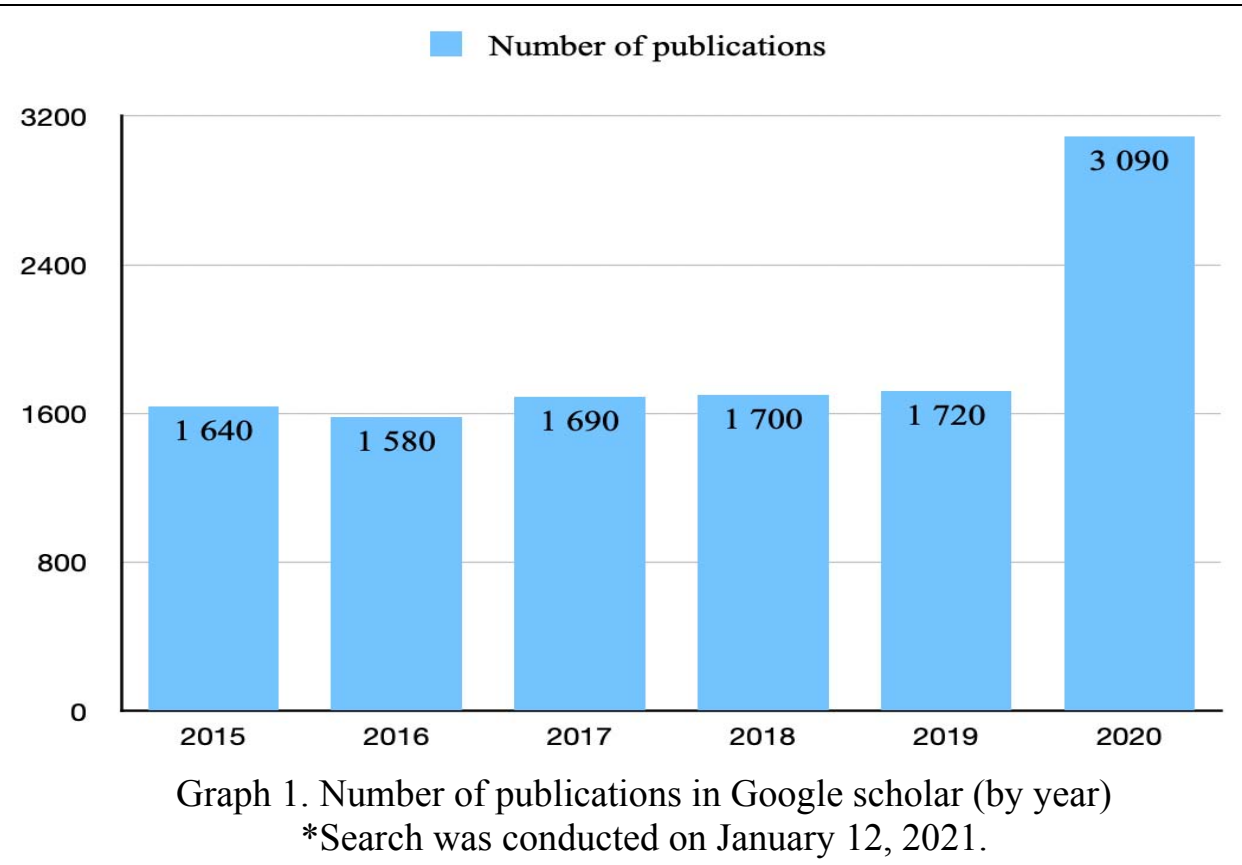

Such interest can be explained by the need to analyze the effects and find ways to deal with the changes brought by the COVID-19 pandemic to the educational system.

One of the most thorough researches on the attitude of Ukrianian university students towards blended learning is made by Liashenko and Hnapovska (2019). They investigate the acceptance of blended learning among 100 Sumy State University students with different majors and conclude that only $5 \%$ of students did not support the blended learning experience at all (p. 153), while more than $80 \%$ like it much more than traditional classroom approach (p. 154). However, the figures might differ a lot when it comes to the students majoring in philology, as learning language requires many specific skills and competences for successful communication. As such, to fill the existing gap, current research focuses on CFL students only.

Research Questions. Current paper aims to answer the following research questions:

1. How do CFL students evaluate their computer literacy and readiness to learn online?

2. What is the CFL students' perception towards the effectiveness of distance education towards the development of different skills in comparison to the traditional classroom? 
ISSN 2078-5526. Вісник Львівського університету. Серія педагогічна. 2021. Випуск 35

Methodology. This section covers the information on participants, data collection and analysis processes.

Participants. Current research targets 40 BA University students who learned Chinese as a Second Language (CSL) in two institutions: Kyiv National Linguistic University (Kyiv, Ukraine) and International Humanitarian University (Odessa, Ukraine). The first one (KNLU) is a public university that conducts classes online through Microsoft Teams platform. The second one (IHU) is a private institution that gives more freedom to its academic staff and allows instructors to choose a convenient platform. The majority of classes are held through Zoom sessions; however, some teachers prefer to use Moodle and Skype instead. Both institutions encourage academic staff to use other supportive online resources to make the learning process more engaging and organized, for instance Quizlet, Kahoot!, Google forms, YouTube, Pinterest, Edmodo and others. The paper regards such a difference in teaching methods as a plus, as it covers the CSL students who use different platforms, thus the collected results are universal. Graph 2 below presents the detailed information on the participants and as one can note the number of representatives from the two universities and from each course is pretty much the same.

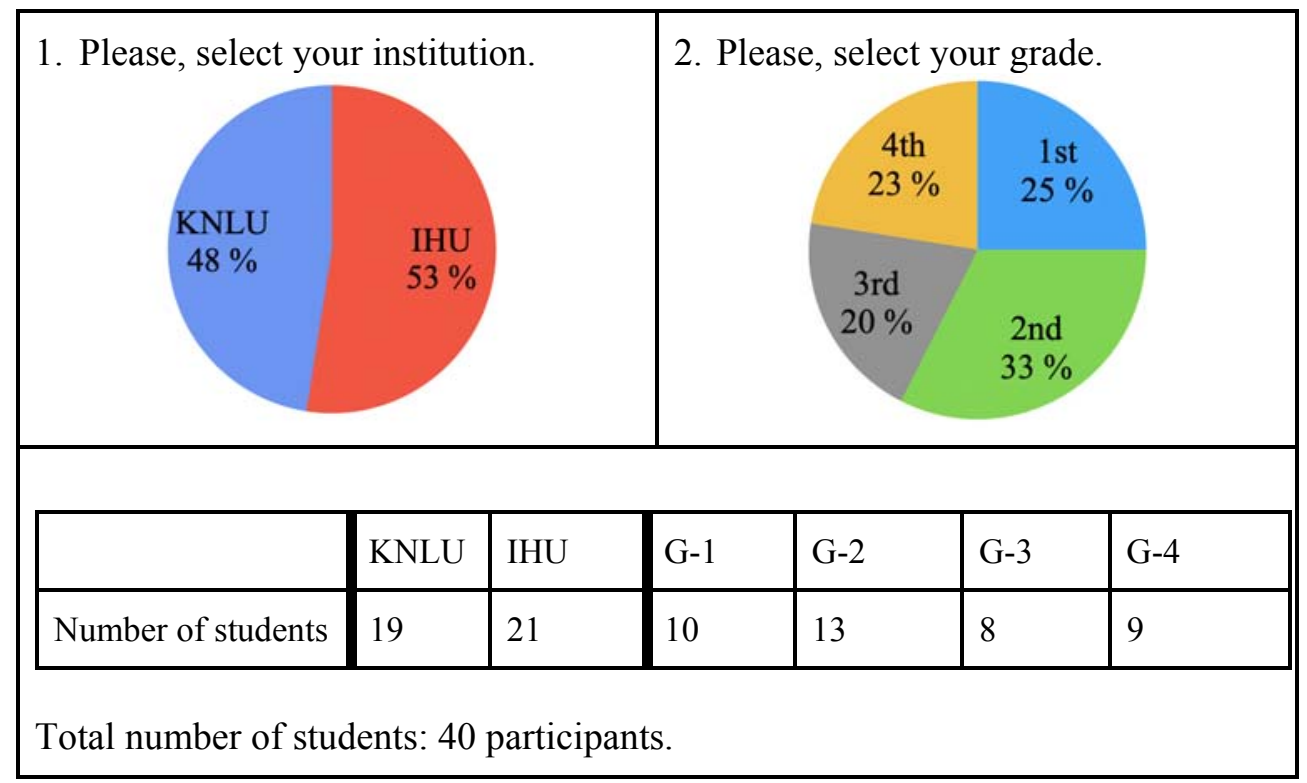

Graph 2. Background of the participants

Data Collection and Analysis. The data collection and analysis process was held online via Google Forms during the last week of the first semester in 2020. All 
ISSN 2078-5526. Вісник Львівського університету. Серія педагогічна. 2021. Випуск 35

participants filled in an anonymous online questionnaire that is based on a model proposed by Al Zumor et al. (2013) for measuring EFL (English as a foreign language) students' perception towards the impact of blended learning on the development of different skills and competencies. The questionnaire consisted of two main sections: the first one collects information on the participants, while the second consists of 19 Likert-type statements focused on language skills and on the possible challenges faced by those who learn online in comparison to those who stick to a traditional classroom.

Results and Discussion. In order to answer the key research question (RQ\#2), one should first assess students' attitude towards the switch in educational paradigms and teaching methods. Thus, the first research question (RQ\#1) aims to shed the light on how learners evaluate their readiness to study outside of the traditional classroom.

Research Question \#1. The graph 3 shows that only $10 \%$ of respondents believe that a traditional classroom is still the best way to organize learning process, while $90 \%$ state that they prefer completely distant online education $(22.5 \%)$ or the combination of both environments $(67.5 \%)$. This finding corresponds to the results shared by Liashenko and Hnapovska (2019). It becomes obvious that the global trend of "updating" learning process has finally reached Ukraine.

\section{Which form of education do you prefer the most?}

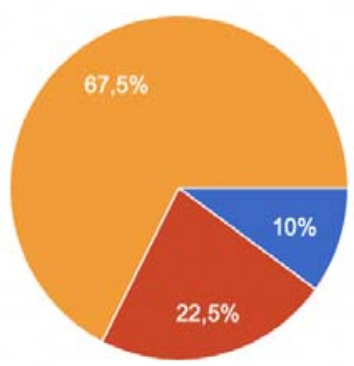

Traditional classroom

Distance (online) learning

Blended classroom (mix of both)

Graph 3. The choice of educational model

Moreover, it is important to find out how students assess their computer literacy skills. ICT competency is crucial for successful integration of modern ways of teaching and learning, as the frustration towards how to use the online educational platform may affect learning outcomes and preferences in learning styles (Khoruzha, Proshkin, Kotenko, \& Smyrnova-Trybulska, 2019). Graph 4 
shows how students assess their skills and, thus, how easy they can participate in online learning activities.

How do you rate your computer literacy?

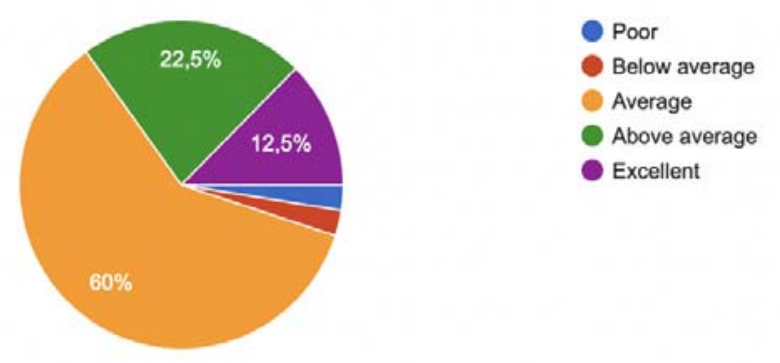

Graph 4. Students' self-assessment of computer literacy skills

As seen from the graph above, only $5 \%$ of the students believe that they have poor $(2.5 \%)$ and below average $(2.5 \%)$ level of computer literacy skills. $60 \%$ of respondents state that they have average skills that are enough for effective online communication. At the same time, $35 \%$ of respondents report to have strong $(22.5 \%)$ and excellent (12.5\%) computer literacy.

Research Question \#2. The main aim of the paper is to investigate how distant education with blended model affects the development of different language skills and competencies among university students who learn Chinese as a foreign language. Graph 5 represents students' attitude towards the effectiveness of blended model in comparison to the traditional classroom.

When compared to the traditional classroom, distance learning helps me better develop my

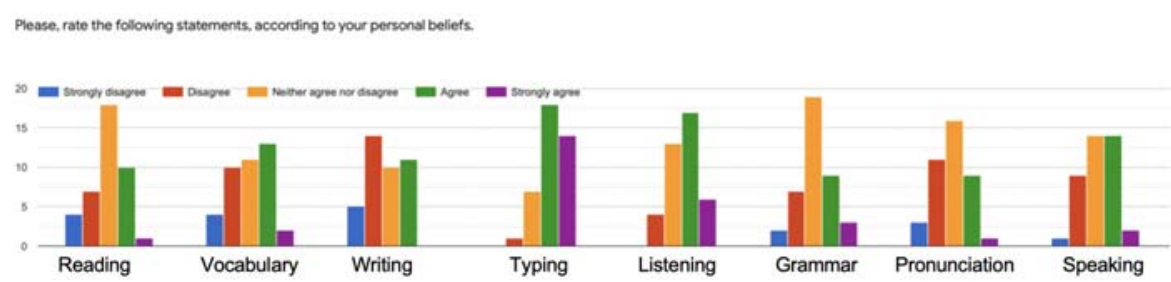

Graph 5. Students' perception of the effectiveness of distance education for different language skills and competences in comparison to traditional classroom

It is worth noting that even though the analysis of RQ\#1 shows that students are ready and willing to switch to blended learning, more than a quarter of 
ISSN 2078-5526. Вісник Львівського університету. Серія педагогічна. 2021. Випуск 35

answers to RQ\#2 (25.6\%) show that learners think that blended learning is less effective than a traditional classroom approach when it comes to learning outcomes. As one can see from Table 1,33.8\% of responses neither agree nor disagree that distance learning affects the development of skills. Of course, this number varies from skill to skill (and the paper will analyze it in further subsections), but the truth is that learners do not see much difference in learning outcomes from distance and traditional learning when asked indirect questions. Moreover, the statistics indicate that the only skill which seems to have more negative marks (35\% disagree and $12.5 \%$ strongly disagree) is writing. However, the situation is compensated by the successful development of typing skills ( $45 \%$ agree and $35 \%$ strongly agree), which is extremely important for character-based languages like Chinese.

Table 1. Students' perception of the effectiveness of distance education in comparison to traditional classroom (data from Graph 5)

Rating

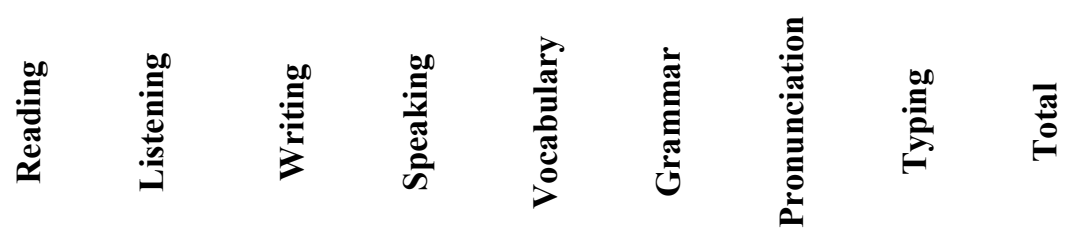

\begin{tabular}{lccccccccc}
$\begin{array}{l}\text { Strongly } \\
\text { agree }\end{array}$ & $\begin{array}{c}1 \\
(2.5 \%)\end{array}$ & $\begin{array}{c}6 \\
(15 \%)\end{array}$ & $(0 \%)$ & $(5 \%)$ & $(5 \%)$ & $(7.5 \%)$ & $(2.5 \%)$ & $(35 \%)$ & $(9 \%)$ \\
\hline Agree & 10 & 17 & 11 & 14 & 13 & 9 & 9 & 18 & 101 \\
& $(25 \%)$ & $(42.5 \%)$ & $(27.5 \%)$ & $(35 \%)$ & $(32.5 \%)$ & $(22.5 \%)$ & $(22.5 \%)$ & $(45 \%)$ & $(31.6 \%)$ \\
$\begin{array}{l}\text { Neither } \\
\text { agree } \\
\text { nor } \\
\text { disagree }\end{array}$ & 18 & 13 & 10 & 14 & 11 & 19 & 16 & 7 & 108 \\
& $(45 \%)$ & $(32.5 \%)$ & $(25 \%)$ & $(35 \%)$ & $(27.5 \%)$ & $(47.5 \%)$ & $(40 \%)$ & $(17.5 \%)$ & $(33.8 \%)$ \\
Disagree & 7 & 4 & 14 & 9 & 10 & 7 & 11 & 1 & 63 \\
& $(17.5 \%)$ & $(10 \%)$ & $(35 \%)$ & $(22.5 \%)$ & $(25 \%)$ & $(17.5 \%)$ & $(27.5 \%)$ & $(2.5 \%)$ & $(19.7 \%)$ \\
$\begin{array}{l}\text { Strongly } \\
\text { disagree }\end{array}$ & $(10 \%)$ & 0 & 5 & 1 & 4 & 2 & 3 & 0 & 19 \\
& $(0 \%)$ & $(12.5 \%)$ & $(2.5 \%)$ & $(10 \%)$ & $(5 \%)$ & $(7.5 \%)$ & $(0 \%)$ & $(5.9 \%)$
\end{tabular}

In order to better understand how the application of distance learning affects the development of different skills, authors propose to group them in receptive (reading and listening) and productive (writing and speaking). The same approach was suggested by Bahari and Salimi (2021) who investigated the same topic from the teachers' point of view. Secondly, the paper will separately analyze the impact of distance education on the vocabulary, grammar and pronunciation. And the last 
ISSN 2078-5526. Вісник Львівського університету. Серія педагогічна. 2021. Випуск 35

but not least, the paper will focus on a new category "typing skills", as typing is an additional skill required for anyone who learns character-based languages like Chinese.

Receptive skills. The analysis shows that the majority of learners (81\%) believe that blended learning is at least the same effective for the development of receptive skills as the traditional classroom is (Table 2). Only 19\% of answers point that distance education may somewhat complicate the development of reading and listening skills. Moreover, $42 \%$ of answers point to the fact that a blended model facilitates the development of the aforementioned skills. This outcome corresponds with that of findings of Al Zumor et al. (2013) and those of Bataineh and Mayyas (2017). On the one hand, online learning resources are easy to share and have high quality. On the other hand, the quality of listening or reading materials presented in-class is subjected to the outside factors such as noise, angle of view, distance for the source etc. Therefore, the retrieved results in this particular case are quite predictable.

Table 2 Perception of the Development of Receptive skills (data from Graph 5)

\begin{tabular}{lccccc|}
\hline & $\begin{array}{c}\text { Strongly } \\
\text { disagree }\end{array}$ & Disagree & $\begin{array}{l}\text { Neither agree } \\
\text { nor disagree }\end{array}$ & Agree & $\begin{array}{l}\text { Strongly } \\
\text { agree }\end{array}$ \\
\hline Reading & 4 & 7 & 18 & 10 & 1 \\
Listening & 0 & 4 & 13 & 17 & 6 \\
\hline Total & $4(5 \%)$ & $11(14 \%)$ & $31(39 \%)$ & $27(34 \%)$ & $7(8 \%)$
\end{tabular}

Productive skills. $64.5 \%$ of responses point to the fact that blended learning is at least the same effective for the development of productive skills as traditional classroom is (Table 3). However, $35.5 \%$ of answers indicate that learners have difficulties with sharing their thoughts (both in written and oral forms) when compared to traditional face-to-face in-class communication. This figure is quite high and poses new challenges to the educational system. Further researchers should be done to see what strategies can help improve the development of productive skills within the blended model.

Table 3. Perception of the Development of Productive skills (data from Graph 5)

\begin{tabular}{lccccc|} 
& $\begin{array}{c}\text { Strongly } \\
\text { disagree }\end{array}$ & Disagree & $\begin{array}{c}\text { Neither } \\
\text { agree nor } \\
\text { disagree }\end{array}$ & Agree & $\begin{array}{c}\text { Strongly } \\
\text { agree }\end{array}$ \\
Writing & 5 & 14 & 10 & 11 & 0 \\
Speaking & 1 & 9 & 14 & 14 & 2 \\
Total & $6(7,5 \%)$ & $23(28 \%)$ & $24(30 \%)$ & $25(32 \%)$ & $2(2,5 \%)$
\end{tabular}


Vocabulary. The majority of participants state that blended model helps them better grasp new vocabulary $(37.5 \%)$, while $27.5 \%$ see no difference with the traditional approach (Table 1). Such results correlate with those of many previous researchers and can be attributed to the wide range of online applications, websites and platforms for vocabulary acquisition (Al Zumor et al., 2013; Khodaparast, \& Ghafournia, 2015; Pertiwi, 2018; Djiwandono, 2018). However, it contradicts the findings of Saengsawang (2020) who conducted the same research in Thailand. The researcher concludes that even though blended learning is "perceived in a positive and feasible way, it may only be applicable for some particular groups or types of learners" (Saengsawang, 2020, p. 307). As seen from the current research, university students believe that blended learning pushes their academic achievements in terms of vocabulary. However, in order to see the real-life effectiveness, one should conduct more researches, especially from teachers' perspective.

Grammar. As indicated in Table 1, the majority of students sees no difference in learning grammar through traditional or blended model $(47.5 \%)$. However, $30 \%$ believe that the blended model facilitates the learning process. This result correlates with those of Bataineh and Mayyas (2017) who state that the experimental group that applied a blended approach outperformed the control one that used a traditional classroom in terms of grammar and reading.

Pronunciation. As pronunciation is a part of speaking competence the figures in these two sections are nearly the same (Table 1). Those who have issues while developing speaking skills during blended learning find it difficult to improve their pronunciation as well. It is worth noting that there is little research on the effect of blended learning on oral proficiency. The majority of available publications just either share personal experience on how to improve pronunciation (Yan, \& Li, 2019; Hamsia, Riyanto, \& Arianto, 2020) or focus on the motivation and anxiety (Wichadeeq, 2017). Thus, this topic is extremely accurate and requires further investigations.

Typing skills. Table 1 shows that $80 \%$ of students agree that blended learning promotes typing skills much better than a traditional classroom $(35 \%$ strongly agree and $43 \%$ agree). This aspect is extremely important for learning character-based languages like Chinese. Even though it is crucial to master handwriting when learning eastern languages, one has to admit that a huge part of communication and documentation is held online. Therefore, typing becomes more and more important nowadays. When compared to letter-based languages, typing in Chinese has many peculiarities. Moreover, previous studies confirm that a switch from handwriting to typing may negatively affect the subsequent character recognition in CFL learners, thus, hinder the development of vocabulary (Longcamp, Boucard, Gilhodes, \& Velay, 2006; Wang, \& East, 2020). However, when it comes to the essay writing competence (productive skill), previous 
ISSN 2078-5526. Вісник Львівського університету. Серія педагогічна. 2021. Випуск 35

researches do not see any correlation between the proficiency and in-put type, either handwriting or typing (Zhang, \& Min, 2019). Taking into account the importance of both skills (handwriting and typing), teachers have to pay enough attention to both of them regardless of the model used (either blended or traditional).

Conclusion. To meet the new challenges set by the rapid development of modern society and the crisis of COVID-19, Ukraine as well as the rest of the world had to adjust its educational system. This paper sheds the light on how such changes affect students who major in Chinese Philology. The findings indicate that the majority of respondents (1) support the move towards distance education in the form of blended learning, (2) affirm that they have enough ICT skills to participate in online activities, and (3) do not think that new education environment can harm the effectiveness of their academic performance. Students report that the only skill which is negatively affected by the blended learning is writing, but earlier researches conducted by Zhang and Min (2019) state that there is no proven statistical correlation between the input type (handwriting or typing) on the development of writing competence. Thus, teachers should pay more attention to the typing skills to improve the development of written productive skill in blending learning environment.

1. Al Zumor A. W. Q., Al Refaai I. K., Eddin E. A. B., \& Al-Rahman F. H. A. EFL students' perceptions of a blended learning environment: Advantages, limitations and suggestions for improvement. English Language Teaching, 6 (10), 2013. P. 95-110. http://dx.doi.org/10.5539/elt.v6n10p95

2. Bahari A., \& Salimi M. Challenges and affordances of developing receptive and productive skills via technology-based instruction. ComputerAssisted Language Learning Electronic Journal, 22 (1), 2021. P. 22-52.

3. Bataineh R. F., \& Mayyas M. B. The utility of blended learning in EFL reading and grammar: A case for Moodle. Teaching English with Technology, 17 (3), 2017. P. 35-49.

4. Cahapay M. B. Rethinking education in the new normal post-COVID-19 era: A curriculum studies perspective. Aquademia, 4 (2), ep 20018. 2020. https://doi.org/10.29333/aquademia/8315

5. Djiwandono P. I. The effect of blended learning on reading abilities, vocabulary mastery, and collaboration among university students. The New English Teacher, 12 (1), 2018. P. 23-24.

6. Hamsia W., Riyanto $Y$., \& Arianto F. Utilizing a new technology of English discoveries platform in implementation of blended learning to improve 
ISSN 2078-5526. Вісник Львівського університету. Серія педагогічна. 2021. Випуск 35

English speaking performance. Journal of English Language Teaching, 7 (2), 2020. P. 68-73. https://doi.org/10.33394/jo-elt.v7i2.3191

7. Kanuka H., \& Rourke L. Using blended learning strategies to address teaching development needs: How does Canada compare? Canadian Journal of Higher Education, 43 (3), 2014. P. 19-35. https://www.learntechlib.org/p/157512/

8. Khodaparast F., \& Ghafournia N. The effect of asynchronous/synchronous approaches on English vocabulary achievement: A study of Iranian EFL learners. English Language Teaching, 8 (4), 2015. P. 117 127. http://dx.doi.org/10.5539/elt.v8n4p117

9. Khoruzha L., Proshkin V., Kotenko O., \& Smyrnova-Trybulska E. Digital competence: Abilities of a lecturer and expectations of students (Ukrainian-Polish context). In W. E. Smyrnova-Trybulska (ed.), E-learning and STEM Education (p. 421-439). Katowice-Cieszyn : Studio Noa for University of Silesia. 2019. http://hdl.handle.net/20.500.12128/12136

10. Liashenko I., \& Hnapovska L.. Blended education: Patterns of implementation at Sumy state university. Revista Romaneasca pentru Educatie Multidimensionala, 11 (3), 2019. P. 141-162. https://doi.org/10.18662/rrem/142

11. Longcamp M., Boucard C., Gilhodes J. C., \& Velay J. L. Remembering the orientation of newly learned characters depends on the associated writing knowledge: A comparison between handwriting and typing. Human Movement Science, 25 (4-5), 2006. P. 646-656. https://doi.org/10.1016/j.humov.2006.07.007

12. Morze N., \& Smyrnova-Trybulska E. Web-based community-supported online education during the COVID-19 pandemic. International Journal of Web Based Communities, $17 \quad$ (1), 2021. P. 9-34. https://doi.org/10.1504/IJWBC.2021.112858

13. Pertiwi D. R. Blended learning to improve the students' vocabulary mastery for mechanical engineering purposes at STT Adisutjipto Yogyakarta. ADJES (Ahmad Dahlan Journal of English Studies), 5 (1), 2018. P. 1-11.

14. Saengsawang $P$. The use of blended learning to support vocabulary learning and knowledge retention in Thai tertiary EFL classrooms (Doctoral dissertation). Durham University. Retrieved from: 2020. http://etheses.dur.ac.uk/13762/1/Saengsawang000612095.pdf?DDD29+

15. Stukalo N., \& Simakhova A. COVID-19 impact on Ukrainian higher education. Universal Journal of Educational Research, 8 (8), 2020. P. 3673-3678. https://doi.org/10.13189/ujer.2020.080846

16. Wang D., \& East M. Constructing an emergency Chinese curriculum during the pandemic: A New Zealand experience. International Journal of Chinese Language Teaching, 1 (1), 2020. P. 1-19. https://doi.org/10.46451/ijclt.2020.06.01

17. Wichadeeq $S$. A development of the blended learning model using Edmodo for maximizing students' oral proficiency and motivation. International 
ISSN 2078-5526. Вісник Львівського університету. Серія педагогічна. 2021. Випуск 35

Journal of Emerging Technologies in Learning, 12 (2), 2017. P. 137-154. https://doi.org/10.3991/ijet.v12i02.6324

18. Yan $H$., \& Li Y. A blended learning approach to EFL pronunciation training. International Symposium on Educational Technology (ISET), Hradec Kralove, Czech $\quad 2019 . \quad$ Pepublic, 105-108, https://doi.org/10.1109/ISET.2019.00030

19. Zhang $Q$., \& Min $G$. Chinese writing composition among CFL learners: A comparison between handwriting and typewriting. Computers and Composition, 54 (1), 2019. P. 102522. https://doi.org/10.1016/j.compcom.2019.102522

20. Zhang $W$. \& Zhu C. Impact of blended learning on university students' achievement of English as a second language. International Journal on E-Learning, 17 (2), 2018. P. 251-273. Retrieved from https://www.learntechlib.org/p/171512

Стаття: надійшла до редколегії 09.08.2021

доопрацьована 18.08.2021

прийнята до друку 20.08.2021

\title{
СТАВЛЕННЯ СТУДЕНТІВ, ЩО ВИВЧАЮТЬ КИТАЙСЬКУ МОВУ ЯК ІНОЗЕМНУ, ДО ДИСТАНЦЙНОЇ ОСВІТИ (ЗМІШАНА МОДЕЛЬ) ПІД ЧАС ПАНДЕМІЇ COVID-19 В УКРАЇНI
}

\author{
Ольга Далте \\ Київський національний лінгвістичний університет, \\ вул. Велика Васильківська, 73, Київ, Україна, UA-03150 \\ olha-dalte@knlu.edu.ua
}

У зв'язку з пандемією COVID-19 Україна разом 3 іншими державами по всьому світу змушена була негайно перевести навчальний процес в онлайн формат, задля запобігання стрімкому розповсюдженню інфекції. Стаття має на меті проаналізувати ставлення студентів-бакалаврів, що вивчають китайську як іноземну мову, до такої радикальної зміни у їх навчальному процесі. Зважаючи на те, що студенти є одними з головних стейкхолдерів будь-якого освітнього процесу, заклади вищої освіти повинні чітко розуміти їх ставлення до нового формату навчання, а також стосовно ефективності дистанційної освіти у формі змішаної моделі. Насамперед надзвичайно важливо чітко зрозуміти, як така швидка зміна освітнього процесу вплинула на розвиток вимови, поповнення словникового запасу, навичок граматики, уміння друкувати, а також на базові рецептивні (аудіювання та читання) i продуктивні (говоріння та письмо) навички.

Для того, щоб відповісти на поставлене вище запитання, стаття аналізує дані, отримані за допомогою анонімного онлайн опитування, проведеного на основі Google Forms. Головними респондентами стали 40 студентів-бакалаврів, що вивчають китайську мову як основну іноземну у двох вищих навчальних закладах, а 
Olha Dalte

ISSN 2078-5526. Вісник Львівського університету. Серія педагогічна. 2021. Випуск 35

саме: Київському національному лінгвістичному університеті (Київ, Україна) та у Міжнародному гуманітарному університеті (Одеса, Україна). Той факт, що ці заклади вищої освіти використовують різні методи, плани та засоби навчання, допоможе отримати чітку неупереджену картину ставлення студентів, тим самим підкріпить надійність отриманих результатів дослідження. Результати дослідження свідчать про те, що потрібно змінювати застарілу модель класичного навчального процесу, отже, студенти не бояться викликів, що ставить перед ними нова змішана форма навчання. Дані підтверджують, що студенти, будучи головними стейкхолдерами освітнього процесу, повністю підтримують запровадження світових трендів на використання новітніх технологій у навчання. Більшість респондентів уважають, що нова змішана форма навчання щонайменше така ж ефективна для вивчення східних мов, як i традиційна. Студенти сподіваються, що, навіть коли суспільство нарешті зможе перемогти пандемію COVID-19, у них буде можливість обирати змішану модель освітнього процесу, адже вона є ефективною, зручною та заохочує до навчання. Крім того, стаття аналізує ставлення студентів до нового навчального середовища через призму попередніх досліджень.

Ключові слова: дистанційна освіта, змішана модель навчання, традиційне навчання, ставлення студентів, вивчення китайської мови як іноземної. 